IRA-International Journal of Management \& Social Sciences

ISSN 2455-2267; Vol.03, Issue 03 (2016)

Institute of Research Advances

http://research-advances.org/index.php/RAJMSS

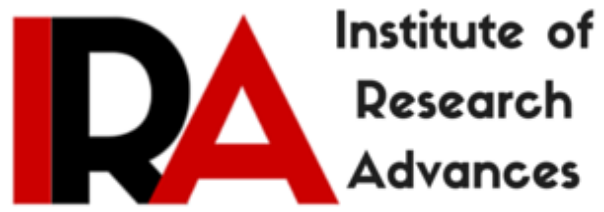

\title{
Peasant Class Differentiation and Differentiated Structure of Credit: A Study of West Bengal, India
}

\section{Gouriprasad Nanda}

Phd Research Scholar in Economics, Department of Economics and Politics,

Visva-Bharati University Santiniketan 731 235, West Bengal, India.

DOI: http://dx.doi.org/10.21013/jmss.v3.n3.p18

\section{How to cite this paper:}

Nanda, G. (2016). Peasant Class Differentiation and Differentiated Structure of Credit: A Study of West Bengal, India. IRA-International Journal of Management \& Social Sciences (ISSN 2455-2267), 3(3).

doi:http://dx.doi.org/10.21013/jmss.v3.n3.p18

(C) Institute of Research Advances

\section{(cc) EY-NC}

This works is licensed under a Creative Commons Attribution-Non Commercial 4.0 International License subject to proper citation to the publication source of the work.

Disclaimer: The scholarly papers as reviewed and published by the Institute of Research Advances (IRA) are the views and opinions of their respective authors and are not the views or opinions of the IRA. The IRA disclaims of any harm or loss caused due to the published content to any party. 


\begin{abstract}
This paper based on primary field survey deals with the nature and extent of peasant class differentiation and the differentiated structure of credit. Accessibility and distribution of credit will be our major concern of investigation. Particularly, we shall try to explore the role of institutional credit in the process of differentiation. The analysis made in this paper would help us to know first of all, to what extent households are dependent on private sources of credit vis-à-vis the institutional sources, secondly, whether credit absorption has something to do with the intensity of class differentiation.
\end{abstract}

Key Words: Class Differentiation; Rural Credit; Exploitation; Agrarian Structure. JEL classification: O13, O16, Q14, Q15

\title{
1. INTRODUCTION
}

West Bengal is an eastern regional state in the Indian federal structure. This state is mainly inhibited with the Bengali speaking population. Before the Indian independence in 1947 the West Bengal and now Bangladesh remained under a unified state Bengal. At the time of independence, West Bengal inherited a de-industrialised structure of the economy and a stagnant agrarian structure. A huge influx of Hindu refugee from East Bengal only multiplied the problem. The agrarian structure was dominated by the retrogressive elements like landlords, moneylenders, traders who found most favourable environment to grow under colonialism. In these context poor peasants in West Bengal along with the other parts of the country started to revolt immediately after the independence under the leadership of peasant organisations of the Left parties. Tebhaga was the name of a famous peasant movement in independent India where poor tenants demanded one third of total crop share. Government of India on the one hand brutally suppressed the peasant movements and passed various pro poor land reform acts on the other favouring the poor peasants. Though, the latter were totally eye-washing in the sense that all these acts were shelved unimplemented. The Left parties gained under this situation. They mobilised the poor peasants against the government's inaction in land reform and ultimately dislodged the Congress Party from power. Both under the United Front Government and Left Front Government the West Bengal experienced important agrarian change that we will discuss in course of our analysis.

Since 1991, the policy of economic liberalization [New Economic Policy (NEP)] was introduced in Indian agriculture. West Bengal as a state of Indian federal structure had to accept this policy of reform even as a bitter pill. The direct and immediate impact of this policy was to cut in food and fertiliser subsidies and therefore a rise in fertiliser price. The reduction in food and fertiliser subsidies came as a direct consequence of the recommendation of the Fund/Bank as a main conditionality of structural adjustment programmes to cut down the non-plan budgetary expenditure in order to reduce fiscal deficits. Since the fertilizer was used on more than 85 per cent of irrigated land and about 50 per cent of un-irrigated land by 1988-89 [Rao and Gulati, 1994], such a unilateral withdrawal of fertiliser subsidies is bound to have a detrimental impact on the economy. In the rural credit front, NEP from its inception was in favour of the abolition of all concessional rates of interest. Narasimham Committee on financial sector reform recommended that the priority sector lending should be slashed down from 40 per cent to 
10 per cent. Though the government has postponed action on this particular recommendation, but it has otherwise shown a positive response towards 'progressive dis-involvement in rural credit for commercial bank' [Krishnaswamy, 1994] by taking decision to close down all the loss making branches of the commercial bank located in rural areas. Thus, on rural credit front the NEP implies a policy of a credit squeeze in agriculture. At the same time government wished to strengthen the micro credit alternative. Since the micro credit suits fine with the agenda of liberalization and privatization and it does not involve any state support, government was keen to explore this alternative.

In West Bengal also an attempt has been made to orient the development through the microfinance and Self-Help groups and they are Largely Govt. operated. Our prime motive is to enquire what are the real causes and effects of stress in supplementing development policy oriented towards Rural Finance with the ongoing institutional reforms.

\section{SURVEY DESIGN AND METHODOLOGY}

This analysis is based on field surveys conducted in the year 2010-11 among 206 sample households in two parts of Birbhum district of West Bengal. We have purposively chosen the Birbhum district as it is able to capture the diversity in the topography and population distribution. Moreover for our purpose Birbhum has some relative advantages over the other districts as it is not proximate to the state capital. It is a common phenomenon that, a district nearer to the state capital will have a higher level of economic development. Again any sample region proximate to the state capital may get added attraction of the policy makers in terms of higher inflow of credit. Therefore any survey conducted in districts nearer to the state capital may give a biased and over-estimated view of the credit distribution in the state.

The other criteria related to overall development which had an influence on selections of the two districts are drafted below-

First, often called "The Land of red soil", Birbhum is noted for its topography as it is somewhat different from that of other districts in West Bengal. Apart from the western part, a part of the Chhota Nagpur platau, which is a bushy region the major part of the district is covered by the fertile alluvial farmlands with major rivers like Ajay, Mayurakshi, Kopai, Bakreshwar, Brahmani, Dwarka, Hinglo etc. River Ajay forms the boundary between the districts of Birbhum and Bardhaman. Annual average rainfall in Birbhum district is 1,300 millimeters. Secondly, in Birbhum, majority (around 63\%) of the inhabitants are dependent on agriculture.

Two sample blocks are selected, namely relatively advanced and the relatively backward block. We have used seven development indicators to identify these blocks, namely Nalhati-II and Illambazar as the most advanced and the most backward respectively. We have chosen two moujas Bara and Chotochak took respectively from Nalhati-II and Illambazar. These two sample moujas (Bara from Nalhati-II and Chhotochalk from Illambazar) are purposively selected on the basis of the size and ethnic distribution of population, level of land reform and other development indicators (Appendix - I).

We use the method of simple random sampling without replacement for selecting the sample households. We classify our 206 sample households (of which 105 households belong to the backward region) on the basis of Patnaik's (1987) E-criterion 
(see, Appendix - II), side by side with the usual classification by acreage. A detailed account of the classification of households is given in the next section.

Patnaik's E-criterion is particularly relevant for the ground reality of West Bengal. West Bengal agriculture in recent period has witnessed a massive decline in the proportion of population belonging to the higher size groups. Particularly the NSSO 48th round data revealed a liquidation of the size group 10 acres and above by the year 1991 . In our sample we have found a single household above 5 acres of landsize. On the other hand 91 out of 206 households (44\%) belong to the marginal size group (0.01 to 2.5 acres). On the other hand the census data showed a decline in the agricultural labour population. Considering the acreage classification alone it might appear that the peasant class differentiation has been come to a halt in West Bengal. However our analysis will show how class differentiation is still going on based on the command over assets, irrigation, inputs, outputs, product marketed and to some extent credit. In other words, classification of households based on Patnaik's E criterion would show us the true face of this differentiation based on tiny land holdings and increasing concentration of command over assets. The most disturbing phenomenon is the landless households registered 70 out of 206 households (34\%) which according to our survey is the contribution of last two decades of liberalization policy.

\section{CLASSIFYING THE HOUSEHOLDS}

As mentioned earlier that we have classified the households by two different criteria - farm size and labour use. The distribution of sample households according to the two criteria for the advanced and the backward regions as well as for both regions combined is presented in the Table-1. This table shows the number of the households according to cross-classification using the two criteria namely, economic class and operated land size. Some general observations follow. First, while the two criteria are associated, as we would expect, they are not identical since we get positive non-diagonal elements (especially above the diagonal, not so much below). The number of landless households is however substantial, the category which is identical in both the classifications. 70 households or $34 \%$ of the sample was found to be landless in the proper sense of the term, neither owning any land, nor operating any land. This in itself seems to reflect the incidence of immiserisation and landlessness in the sample villages. Secondly, the modal farm size is below 2.5 acres, with 91 out of 206 households, or $44 \%$ of the sample falling in this group. This high concentration of farms in the smallest farm size group reflects the fact that a large number of landless households had moved up to the 0.01 to 2.5 acreage group by receiving the vested ceiling-surplus land during the Left Front period after 1977. The majority of the households in this acreage group are poor peasants, since we find that 28 out of the 91 or a little more than $31 \%$ fall in this category. However a sizeable proportion, 37 households or nearly $41 \%$ are small or middle peasants, who are mainly self-employed and do not need to sell their labour power to any great extent to the wealthy households. In fact the middle peasants are by definition small net employer of others. Interestingly we find as many as 26 households or 29\% of the total in this size-group (0.01-2.5 acre), fall in the rich peasant and landlord category (mainly or wholly using non-family labour) despite the relatively small size of their farms. They make up nearly $46 \%$ of all rich peasants and landlords.

Looking at the size grouping, we find only a single farm operating above 5 acres with the land size 6.6 acres or $18.34 \%$ of the total area operated (Table 1). The successful acquisition of ceiling surplus land has led to the reduction in the concentration of land in the hands of the erstwhile landlords in the higher acreage groups. But at the same time 
implementation of the ceilings might have induced the need for more intensive cultivation of their reduced areas of land on the part of many of these erstwhile landlords, thus promoting a switch over from rent to capitalist cultivation, as a result of which, their dependence on hired in labour has increased. By and large those who do no manual work themselves - the landlord as defined here, the highest group - hail from the class of erstwhile rentiers, though some are of rich peasant origin, who might have improved their position. Operation Barga has also curbed the former power of the rentiers as effectively as it has guaranteed occupation to the bargadars and reduced the area directly operated by erstwhile landlords (jotedars).

The region wise classification of the data gives further insight. It is quite clear that the structures discussed above are the outcome of structural differences between the advanced region and the backward region. Thus $83 \%$ per cent of farms are below 2.5 acres in the advanced compared to 73\% in the backward region. As much as $51.49 \%$ of farmers are of landless and poor peasant status in the advanced region compared to 43.8\% in the backward region. The corresponding shares in the total number holdings, of the better-off farmers, mainly or wholly using outside labour (the rich peasants and the landlords) are $20 \%$ and $34.29 \%$ t respectively. Thus the mainly self-employed farmers, or the middle groups constitute i.e. $27.72 \%$ and $22 \%$ in the advanced and the backward regions respectively.

The picture becomes clearer when the distribution of total area by economic class and farm size is taken into account. Table-1 presents the cross-classification of the farms according to the two grouping criteria on the basis of which the following observations might be made. First, at the upper end of the size group there is only 1 farm operating above 5 acres or $3.66 \%$. This household belongs to middle peasant in the backward region. This partly supports the hypothesis that the concentration of land has declined owing to the successful implementation of the land reform measures.

However, looking into the distribution of the average area, according to farm size it is observed as expected the average farm size increase steadily with rising size groups up to the fifth group. But it reveals a jump from 1.94 acres to 4.65 acres between the third and the fourth group. This reflects the steep pattern of landholding distribution.

Secondly, the average farm size rises from the poor peasant to the rich peasant though then it drops for landlords. Thus the poor peasants operate 0.38 acres on an average - the small peasants $0.75 \mathrm{acres}$, the middle peasants 1.29 acres, the rich peasants 1.79 acres and the landlords 1.43 acres.

Part of the reason for the drop in the average size of the 'landlord' holdings is that we have not excluded the few 'petty rentier and petty employer' families from this group. The petty rentiers and petty employers do not participate in manual labour. They have small resources and are not in fact big exploiters of outside labour. They are usually obliged to use outside labour owing to the absence of other factors like working in petty service occupations themselves. Strictly speaking these households should not be included in 'landlords' at all since this category is thought of as rentiers and employers. 
IRA-International Journal of Management \& Social Sciences

Table 1: Cross Classification of Number of Households, Average \& Total Area by Economic Class \& Acreage Group (Area in Acres)

\begin{tabular}{|c|c|c|c|c|c|c|c|c|c|c|c|c|c|c|c|c|c|c|c|c|c|}
\hline \multirow{2}{*}{$\begin{array}{l}\text { Ec.Class-> } \\
\text { Ac.Group }\end{array}$} & \multicolumn{3}{|c|}{ Landless } & \multicolumn{3}{|c|}{ Poor Peasant } & \multicolumn{3}{|c|}{ Small Peasant } & \multicolumn{3}{|c|}{ MiddlePeasant } & \multicolumn{3}{|c|}{ Rich Peasant } & \multicolumn{3}{|c|}{ Land Lord } & \multicolumn{3}{|c|}{ Total } \\
\hline & NO & $\mathbf{A A}$ & TA & NO & $\mathbf{A A}$ & TA & NO & $\mathbf{A A}$ & TA & NO & $\mathbf{A A}$ & TA & NO & $\mathbf{A A}$ & TA & NO & $\mathbf{A A}$ & TA & NO & $\mathbf{A A}$ & TA \\
\hline & \multicolumn{3}{|c|}{ All Region } & \multirow{6}{*}{$\begin{array}{c}0 \\
28 \\
0 \\
0 \\
0\end{array}$} & \multirow{2}{*}{0.00} & \multirow[b]{2}{*}{0.00} & \multirow[b]{2}{*}{$\mathbf{0}$} & \multirow[b]{2}{*}{0.00} & \multirow[b]{2}{*}{0.00} & \multirow[b]{2}{*}{$\mathbf{0}$} & \multirow[b]{2}{*}{0.00} & \multirow[b]{2}{*}{0.00} & \multirow[b]{2}{*}{0} & \multirow[b]{2}{*}{0.00} & \multirow[b]{2}{*}{0.00} & \multirow[b]{2}{*}{0} & \multirow[b]{2}{*}{0.00} & \multirow[b]{2}{*}{0.00} & \multirow[b]{2}{*}{70} & \multirow[b]{2}{*}{0.00} & \multirow[b]{2}{*}{0.00} \\
\hline 0.00 & 70 & 0.00 & 0.00 & & & & & & & & & & & & & & & & & & \\
\hline 0.01to 1.25 & $\mathbf{0}$ & 0.00 & 0.00 & & & 10.63 & 20 & 0.53 & 10.53 & 17 & 0.69 & 11.72 & 18 & 0.68 & 12.16 & 8 & 0.63 & 5.05 & 91 & 0.58 & 53.08 \\
\hline 1.25to 2.5 & $\mathbf{0}$ & 0.00 & 0.00 & & 0.00 & 0.00 & 2 & 1.66 & 3.31 & 9 & 1.65 & 14.87 & 13 & 1.82 & 23.69 & 7 & 1.58 & 11.09 & 31 & 1.94 & 60.23 \\
\hline 2.5 to 5 & $\mathbf{0}$ & 0.00 & 0.00 & & 0.00 & 0.00 & 1 & 3.30 & 3.30 & 1 & 2.81 & 2.81 & 8 & 4.27 & 34.15 & 3 & 3.20 & 9.60 & 13 & 4.65 & 60.42 \\
\hline $5 \&$ abv & $\mathbf{0}$ & 0.00 & 0.00 & & 0.00 & 0.00 & $\mathbf{0}$ & 0.00 & 0.00 & 1 & 6.60 & 6.60 & 0 & 0.00 & 0.00 & 0 & 0.00 & 0.00 & 1 & 6.60 & 6.60 \\
\hline Total & 70 & 0.00 & 0.00 & 28 & 0.38 & 10.63 & 23 & 0.75 & 17.14 & 28 & 1.29 & 35.99 & 39 & 1.79 & 69.99 & 18 & 1.43 & 25.74 & 206 & 0.88 & 180.33 \\
\hline & Ad & iced & & & & & & & & & & & & & & & & & & & \\
\hline 0.00 & 39 & 0.00 & 0.00 & $\mathbf{0}$ & 0.00 & 0.00 & $\mathbf{0}$ & 0.00 & 0.00 & $\mathbf{0}$ & 0.00 & 0.00 & 0 & 0.00 & 0.00 & 0 & 0.00 & 0.00 & 39 & 0.00 & 0.00 \\
\hline 0.01to 1.25 & 0 & 0.00 & 0.00 & 13 & 0.39 & 5.01 & 7 & 0.57 & 3.96 & 12 & 0.74 & 8.91 & 6 & 0.65 & 3.91 & 7 & 0.65 & 4.56 & 45 & 0.65 & 29.33 \\
\hline 1.25 to 2.5 & 0 & 0.00 & 0.00 & 0 & 0.00 & 0.00 & 1 & 1.98 & 1.98 & 7 & 1.65 & 11.55 & 3 & 2.09 & 6.27 & 2 & 1.57 & 3.14 & 13 & 2.32 & 30.22 \\
\hline 2.5 to 5 & $\mathbf{0}$ & 0.00 & 0.00 & $\mathbf{0}$ & 0.00 & 0.00 & $\mathbf{0}$ & 0.00 & 0.00 & 1 & 2.81 & 2.81 & 1 & 4.62 & 4.62 & 2 & 3.14 & 6.27 & 4 & 6.06 & 24.26 \\
\hline $5 \&$ abv & o & 0.00 & 0.00 & o & 0.00 & 0.00 & 0 & 0.00 & 0.00 & 0 & 0.00 & 0.00 & 0 & 0.00 & 0.00 & 0 & 0.00 & 0.00 & 0 & 0.00 & 0.00 \\
\hline Total & 39 & 0.00 & 0.00 & 13 & 0.39 & 5.01 & 8 & 0.74 & 5.94 & 20 & 1.16 & 23.26 & 10 & 1.48 & 14.80 & 11 & 1.27 & 13.96 & 101 & 0.83 & 83.80 \\
\hline & Bac & $\operatorname{vard~} \mathrm{F}$ & & & & & & & & & & & & & & & & & & & \\
\hline 0.00 & 31 & 0.00 & 0.00 & $\mathbf{0}$ & 0.00 & 0.00 & $\mathbf{0}$ & 0.00 & 0.00 & o & 0.00 & 0.00 & 0 & 0.00 & 0.00 & 0 & 0.00 & 0.00 & 31 & 0.00 & 0.00 \\
\hline 0.01to 1.25 & $\mathbf{0}$ & 0.00 & 0.00 & 15 & 0.38 & 5.63 & 13 & 0.51 & 6.57 & 5 & 0.56 & 2.81 & 12 & 0.69 & 8.25 & 1 & 0.50 & 0.50 & 46 & 0.52 & 23.75 \\
\hline 1.25 to 2.5 & $\mathbf{0}$ & 0.00 & 0.00 & 0 & 0.00 & 0.00 & 1 & 1.33 & 1.33 & 2 & 1.66 & 3.32 & 10 & 1.74 & 17.42 & 5 & 1.59 & 7.95 & 18 & 1.67 & 30.02 \\
\hline 2.5 to 5 & $\mathbf{0}$ & 0.00 & 0.00 & 0 & 0.00 & 0.00 & 1 & 3.30 & 3.30 & $\mathbf{0}$ & 0.00 & 0.00 & 7 & 4.22 & 29.53 & 1 & 3.33 & 3.33 & 9 & 4.02 & 36.16 \\
\hline $5 \&$ abv & $\mathbf{0}$ & 0.00 & 0.00 & o & 0.00 & 0.00 & o & 0.00 & 0.00 & 1 & 6.60 & 6.60 & 0 & 0.00 & 0.00 & 0 & 0.00 & 0.00 & 1 & 6.60 & 6.60 \\
\hline Total & 31 & 0.00 & 0.00 & 15 & 0.38 & 5.63 & 15 & 0.75 & 11.20 & 8 & 1.59 & 12.73 & 29 & 1.90 & 55.20 & 7 & 1.68 & 11.78 & 105 & 0.92 & 96.53 \\
\hline
\end{tabular}

NOTE: NO=Number, AA=AVERAGE AREA, TA= TOTAL AREA. 
It has been mentioned above that a particular acreage-group is likely to have holdings ranging from poor peasant to rich peasant status. However as we would expect, the proportion of labour-hiring holdings (middle peasants, rich peasants and landlords) in the total holdings by acreage group is found to predominate in the farms above 2.5 acres. However, the converse holds good for the poor and small peasants whose share is higher on smaller farms below 2.5 acres. Thus $100 \%$ of poor peasants and $87 \%$ of small peasants are on farms below 2.5 acres while $54 \%$ of rich peasants and $56 \%$ of landlords are on farms above 2.5 acres.

Table 1 shows a steep concentration in landholding both in the advanced and in the backward region. In the combined region $13.59 \%$ of households belong to poor peasant have only $5.89 \%$ of land under possession. While $18.93 \%$ of households belong to rich peasant have $38.81 \%$ of land. On the other hand $44 \%$ of households belong to the size group below 1.25 acres have land area $29.43 \%$ of land area; while $6.31 \%$ households belong to the size group $2.5-5$ acres have $33.5 \%$ of land area.

Table 2 on the net labour days hired in or out per holding, reveals the variation in the economic status of households within each acreage group. It is quite clear from the table that the class categories successfully isolate holdings of different types with respect to the variables of labour hiring, and therefore show consistently and significantly different mean values for holdings in the different economic classes, regardless of the acreage group they fall into. For example, in the landlord class (in the combined region) labour hiring ranges from 299.8 to 1168 days per annum per holding over the acreage groups, in the rich peasant class the same ranges from 127.5 to 294.5 days per annum per holding over the acreage groups, while for the middle peasant class it ranges from 117.8 to 443.5 days over the acreage groups. For the small-peasants labour hiring ranges from 29.77 to -148 . For the landless and poor peasant it has a uniform value at -203.68 and 114.67 respectively. 
Table 2 Cross Classification of the Net Labour Days HI/HO Per Holdings

\begin{tabular}{|c|c|c|c|c|c|c|}
\hline $\begin{array}{c}\text { Ec. Class-> } \\
\text { Ac. Gp }\end{array}$ & Landless & $\begin{array}{c}\text { Poor } \\
\text { Peasant }\end{array}$ & $\begin{array}{c}\text { Small } \\
\text { Peasant }\end{array}$ & $\begin{array}{l}\text { Middle } \\
\text { Peasant }\end{array}$ & $\begin{array}{c}\text { Rich } \\
\text { Peasant }\end{array}$ & Landlord \\
\hline & \multicolumn{2}{|c|}{ ALL REGION } & & & & \\
\hline 0.00 & -203.68 & 0.00 & 0.00 & 0.00 & 0.00 & 0.00 \\
\hline 0.01 to 1.25 & 0.00 & -114.67 & -29.77 & 117.80 & 127.50 & 1168.00 \\
\hline 1.25 to 2.5 & 0.00 & 0.00 & -148.00 & 443.50 & 251.90 & 299.80 \\
\hline 2.5 to 5 & 0.00 & 0.00 & 0.00 & 0.00 & 294.57 & 1068.00 \\
\hline $5 \&$ abv & 0.00 & 0.00 & 0.00 & 170.00 & 0.00 & 0.00 \\
\hline Total & -203.68 & -114.67 & -35.67 & 206.25 & 210.72 & 533.57 \\
\hline \multicolumn{7}{|c|}{ ADVANCED REGION } \\
\hline 0.00 & -107.44 & 0.00 & 0.00 & 0.00 & 0.00 & 0.00 \\
\hline 0.01 to 1.25 & 0.00 & -65.77 & -18.43 & 44.75 & 93.50 & 158.29 \\
\hline 1.25 to 2.5 & 0.00 & 0.00 & -148.00 & 103.14 & 333.00 & 205.50 \\
\hline 2.5 to 5 & 0.00 & 0.00 & 0.00 & 4.00 & 235.00 & 315.50 \\
\hline $5 \&$ abv & 0.00 & 0.00 & 0.00 & 0.00 & 0.00 & 0.00 \\
\hline Total & -107.44 & -65.77 & -34.63 & 63.15 & 179.50 & 195.45 \\
\hline \multicolumn{7}{|c|}{ BACKWARD REGION } \\
\hline 0.00 & -30.34 & 0.00 & 0.00 & 0.00 & 0.00 & 0.00 \\
\hline 0.01 to 1.25 & 0.00 & -30.89 & -12.90 & 3.06 & 53.83 & 7.50 \\
\hline 1.25 to 2.5 & 0.00 & 0.00 & 0.00 & 18.33 & 116.92 & 155.43 \\
\hline 2.5 to 5 & 0.00 & 0.00 & 0.00 & 0.00 & 228.38 & 145.67 \\
\hline $5 \& a b v$ & 0.00 & 0.00 & 0.00 & 170.00 & 0.00 & 0.00 \\
\hline Total & -30.34 & -30.89 & -11.22 & 13.82 & 110.67 & 88.06 \\
\hline
\end{tabular}

On the other hand, within a given acreage group, such as 0.01-2.5 acres, the labour hiring ranges from -114.67 (hiring out) to 1168 (hiring in). It is clear enough that diametrically opposite types of holdings in terms of labour process get included in every acreage group - both the households which are themselves exploiters of others' labour as well as the households which are themselves exploited. In other words, acreage as an index fails to discriminate between different types of holdings that differs in the crucial respect of labour use and hence the extent to which they remain 'peasant' households.

\section{CLASS DIFFERENTIATION IN VARIOUS AGRARIAN STRUCTURES AND CREDIT}

A detailed account of the differentiation of the peasantry has been derived from our analysis. The essence of the process of differentiation is that with the advent of the capitalist relation in agriculture, the peasant society gets bifurcated into two broad classes, bourgeois and proletariat. The middle peasants get threatened of liquidation owing to the onslaught of the market. The percentage distribution of different variables among classes has been observed from Table 3. It has been seen that the labour hiring classes, namely the rich peasant and the landlord dominates over all means of production. It has been revealed that all the markets namely, asset, land, irrigation, input, output, product marketed show an acute kind of inequality with respect to the distribution of the households among three categories. It is clear from the Table 3 that the distribution of the variables shows a uniform pattern of concentration, where 60 per cent or more cornered by the labour hiring classes, who constitutes around 28.64 per cent per cent of the total holdings. On the other hand the exploited classes that is 46.6 per cent of total holding 
commanding 7 per cent at the most. The self-employed classes on the average have 30 per cent of the resources. However the distribution of credit does not follow this uniform pattern since the exploited classes account for around one-third and the labour-hiring classes below 44 per cent of credit, giving a substantial degree of egalitarianism. Clearly the distribution of institutional credit has not followed the blind logic of the market economy which breeds extreme inequality in the overall structure of production conditions. Yet there is a clear bias towards the labour hiring classes in the existing pattern of credit disbursement. Looking into the Gini Coefficients of different variables it is observed that the institutional credit witnessed the minimum value of Gini coefficients $(0.168)$ while the product marketed exhibited acute concentration with the highest value of Gini coefficient ( 0.577 ) followed by output (0.509).

The size group wise distribution shows that despite the largest concentration of households (44 per cent) in the size group 0.01 to 1.25 acres, the size groups above the 1.25 acres appropriates more than 60 per cent of owned and operated land, irrigation facilities, input, output and product marketed. The non-land assets also show a large concentration of 53 per cent in favour of the same. This reflects an emerging aspect of non-land based concentration of means of production with the emergence of a new class of rural rich in West Bengal. The institutional and non-institutional credits reveal relatively lower degree also greater concentration to the lower size group, 0.01 to 2.5 acres. This gives further justification for choosing the labour exploitation criterion as a device for classifying the households. However, in the case of size groupings the Gini coefficient shows the highest value for the owned land (0.649) followed by productmarketed $(0.628)$. The non-institutional credit $(0.160)$ followed by the non-institutional credit (0.176) show the minimum degree of concentration for the reasons explained above. 
Table 3: Economic Class \& Acreage Gp wise Percentage Distribution of Households, Assets, Land, Irrigation, Input, Output, Product Marketed, Institutional \& Non-institutional Credit

\begin{tabular}{|c|c|c|c|c|c|c|c|c|c|c|}
\hline $\begin{array}{l}\text { Economic Classes/ } \\
\text { Acreage Group }\end{array}$ & Households & Assets & $\begin{array}{l}\text { Owned } \\
\text { Land }\end{array}$ & $\begin{array}{l}\text { Operated } \\
\text { Land }\end{array}$ & $\begin{array}{c}\text { Irrigated } \\
\text { Area }\end{array}$ & Input & Output & $\begin{array}{c}\text { Product } \\
\text { Marketed }\end{array}$ & $\begin{array}{c}\text { Institutional } \\
\text { Credit }\end{array}$ & $\begin{array}{c}\text { Non-Inst } \\
\text { Credit }\end{array}$ \\
\hline All Region & & $\{0.328\}$ & $\{0.553\}$ & $\{0.480\}$ & $\{0.464\}$ & $\{0.482\}$ & $\{0.509\}$ & $\{0.577\}$ & $\{0.168\}$ & $\{0.187\}$ \\
\hline Landless & 33.98 & 12.66 & 0.07 & 0.00 & 0.00 & 0.00 & 0.00 & 0.00 & 23.96 & 22.98 \\
\hline Poor Peasant & 12.62 & 7.18 & 4.19 & 6.67 & 6.88 & 7.07 & 4.86 & 1.85 & 12.01 & 6.77 \\
\hline Small Peasant & 11.17 & 6.22 & 7.76 & 10.74 & 8.56 & 9.50 & 9.69 & 4.47 & 11.01 & 17.29 \\
\hline Middle Peasant & 13.59 & 25.17 & 17.00 & 22.56 & 32.24 & 23.12 & 22.98 & 26.55 & 9.08 & 8.44 \\
\hline Rich Peasant & 19.90 & 33.54 & 48.72 & 43.89 & 34.29 & 44.02 & 42.71 & 38.69 & 29.05 & 30.07 \\
\hline Landlord & 8.74 & 15.24 & 22.26 & 16.14 & 18.04 & 16.29 & 19.75 & 28.43 & 14.89 & 14.45 \\
\hline Total & 100.00 & 100.00 & 100.00 & 100.00 & 100.00 & 100.00 & 100.00 & 100.00 & 100.00 & 100.00 \\
\hline Advanced Region & & $\{0.274\}$ & $\{0.638\}$ & $\{0.503\}$ & $\{0.479\}$ & $\{0.489\}$ & $\{0.543\}$ & $\{0.592\}$ & $\{0.288\}$ & $\{0.175\}$ \\
\hline Landless & 38.61 & 17.54 & 0.00 & 0.00 & 0.00 & 0.00 & 0.00 & 0.00 & 21.97 & 33.42 \\
\hline Poor Peasant & 12.87 & 10.32 & 6.43 & 7.95 & 9.28 & 11.58 & 5.00 & 2.41 & 11.72 & 5.94 \\
\hline Small Peasant & 7.92 & 3.18 & 2.23 & 9.43 & 10.51 & 8.07 & 9.22 & 5.15 & 1.91 & 8.20 \\
\hline Middle Peasant & 19.80 & 39.24 & 23.21 & 36.94 & 39.70 & 36.61 & 33.58 & 33.77 & 20.09 & 12.45 \\
\hline Rich Peasant & 9.90 & 13.66 & 26.22 & 23.50 & 18.22 & 19.11 & 27.22 & 30.98 & 19.22 & 12.91 \\
\hline Landlord & 10.89 & 16.06 & 41.90 & 22.18 & 22.28 & 24.63 & 24.98 & 27.69 & 25.08 & 27.08 \\
\hline Total & 100.00 & 100.00 & 100.00 & 100.00 & 100.00 & 100.00 & 100.00 & 100.00 & 100.00 & 100.00 \\
\hline Backward Region & & $\{0.409\}$ & $\{0.479\}$ & $\{0.448\}$ & $\{0.471\}$ & $\{0.472\}$ & $\{0.484\}$ & $\{0.660\}$ & $\{0.084\}$ & $\{0.164\}$ \\
\hline Landless & 29.52 & 7.15 & 0.09 & 0.00 & 0.00 & 0.00 & 0.00 & 0.00 & 24.84 & 16.75 \\
\hline Poor Peasant & 12.38 & 3.62 & 3.22 & 5.83 & 3.47 & 3.11 & 4.69 & 0.00 & 12.13 & 7.27 \\
\hline Small Peasant & 14.29 & 9.66 & 10.15 & 11.60 & 5.78 & 10.77 & 10.33 & 2.25 & 15.00 & 22.71 \\
\hline Middle Peasant & 7.62 & 9.28 & 14.32 & 13.19 & 21.65 & 11.26 & 8.85 & 2.67 & 4.25 & 6.05 \\
\hline Rich Peasant & 29.52 & 55.99 & 58.44 & 57.18 & 57.07 & 65.91 & 63.36 & 64.19 & 33.36 & 40.31 \\
\hline Landlord & 6.67 & 14.30 & 13.78 & 12.20 & 12.04 & 8.96 & 12.78 & 30.89 & 10.42 & 6.91 \\
\hline Total & 100.00 & 100.00 & 100.00 & 100.00 & 100.00 & 100.00 & 100.00 & 100.00 & 100.00 & 100.00 \\
\hline All Region & & $\{0.391\}$ & $\{0.649\}$ & $\{0.606\}$ & $\{0.555\}$ & $\{0.548\}$ & $\{0.584\}$ & $\{0.628\}$ & $\{0.160\}$ & $\{0.176\}$ \\
\hline 0.00 & 33.98 & 12.66 & 0.07 & 0.00 & 0.00 & 0.00 & 0.00 & 0.00 & 23.96 & 22.98 \\
\hline 0.01 to 1.25 & 44.17 & 32.99 & 27.53 & 31.40 & 37.78 & 37.99 & 33.87 & 27.75 & 41.97 & 41.74 \\
\hline 1.25 to 2.5 & 15.05 & 33.09 & 27.60 & 33.20 & 34.47 & 34.99 & 33.64 & 35.55 & 22.96 & 23.69 \\
\hline 2.5 to 5 & 6.31 & 19.94 & 39.42 & 31.26 & 19.78 & 24.52 & 30.75 & 36.70 & 11.11 & 11.52 \\
\hline $5 \& \mathrm{abv}$ & 0.49 & 1.33 & 5.39 & 4.14 & 7.96 & 2.49 & 1.74 & 0.00 & 0.00 & 0.07 \\
\hline Total & 100.00 & 100.00 & 100.00 & 100.00 & 100.00 & 100.00 & 100.00 & 100.00 & 100.00 & 100.00 \\
\hline Advanced Region & & $\{0.344\}$ & $\{0.610\}$ & $\{0.589\}$ & $\{0.550\}$ & $\{0.546\}$ & $\{0.607\}$ & $\{0662\}$ & $\{0.230\}$ & $\{0.125\}$ \\
\hline 0.00 & 38.61 & 17.54 & 0.00 & 0.00 & 0.00 & 0.00 & 0.00 & 0.00 & 21.97 & 33.42 \\
\hline 0.01 to 1.25 & 44.55 & 38.18 & 41.03 & 41.82 & 46.37 & 47.78 & 39.21 & 31.58 & 46.40 & 39.59 \\
\hline 1.25 to 2.5 & 12.87 & 33.88 & 27.24 & 36.42 & 39.03 & 35.53 & 36.91 & 37.91 & 23.86 & 8.82 \\
\hline 2.5 to 5 & 3.96 & 10.40 & 31.73 & 21.75 & 14.60 & 16.69 & 23.88 & 30.51 & 7.77 & 18.18 \\
\hline $5 \&$ abv & 0.00 & 0.00 & 0.00 & 0.00 & 0.00 & 0.00 & 0.00 & 0.00 & 0.00 & 0.00 \\
\hline Total & 100.00 & 100.00 & 100.00 & 100.00 & 100.00 & 100.00 & 100.00 & 100.00 & 100.00 & 100.00 \\
\hline Backward Region & & $\{0.466\}$ & $\{0.642\}$ & $\{0.609\}$ & $\{0.620\}$ & $\{0.556\}$ & $\{0.592\}$ & $\{0.693\}$ & $\{0.093\}$ & $\{0.171\}$ \\
\hline 0.00 & 29.52 & 7.15 & 0.09 & 0.00 & 0.00 & 0.00 & 0.00 & 0.00 & 24.84 & 16.75 \\
\hline 0.01 to 1.25 & 43.81 & 27.12 & 21.69 & 24.61 & 25.60 & 29.38 & 26.75 & 15.09 & 40.02 & 43.03 \\
\hline 1.25 to 2.5 & 17.14 & 32.19 & 27.75 & 31.09 & 28.01 & 34.53 & 29.28 & 27.77 & 22.57 & 32.57 \\
\hline 2.5 to 5 & 8.57 & 30.71 & 42.74 & 37.46 & 27.14 & 31.41 & 39.91 & 57.13 & 12.57 & 7.55 \\
\hline $5 \& \mathrm{abv}$ & 0.95 & 2.83 & 7.72 & 6.84 & 19.26 & 4.68 & 4.06 & 0.00 & 0.00 & 0.11 \\
\hline Total & 100.00 & 100.00 & 100.00 & 100.00 & 100.00 & 100.00 & 100.00 & 100.00 & 100.00 & 100.00 \\
\hline
\end{tabular}

Note: Figures in parentheses represent Gini-coefficient.

A comparison between the advanced and the backward region shows that economic class wise distribution yields acute kind of inequality in the advanced region where values of the Gini coefficient for most of the variables are higher than that in the backward. This is owing to the higher level of capitalist development in the advanced 
region. It is a matter of fact that in the advanced region 9.90 per cent of rich peasant and 10.89 per cent of landlord together appropriates nearly 68 per cent of owned land, 60 per cent of product marketed and around 40-50 per cent each of operated land, irrigation and output. On the other hand 39 per cent of landless and 12.62 per cent of households belonging to the landless and poor peasant respectively who hold 5 to 10 per cent of the above variables together.

The next question in this study is related to technology. It is a well-known fact that with the introduction of capitalist relation in agriculture, the latter becomes dependent on technology. It is indeed the fact that the technology makes a production condition market dependent. Those who can afford to bear the high priced technological inputs could survive in the market and those who can't, be wiped out. Thus we can expect that in a market economic regime the upper classes have a keen domination over the high yielding technological inputs.

\section{STRUCTURE OF OUTPUT}

The total output per unit area and per holding is shown in Table 4. The advanced region has shown a substantially higher value in comparison to the backward region. The gross output in value terms per holding in the advanced and the backward region Rs 26465 and Rs 21166 respectively. The figures for output per sown areas are Rs 21502 for the advanced region and Rs 16930 for the backward region However, the gap in the output of the advanced and the backward region widens when we take output per operated area in consideration as shown in Table 4. The output per area operated in the advanced region (Rs 42457) is far more (1.84 times) than double of the same in the backward region (Rs 23023). On the other hand the output per sown area in the advanced region (Rs 21502) is only 1.27 times greater than the backward region (16930). The dichotomy between the output per sown area and the output per operated area is explained with the fact that the cropping intensity is far greater in the advanced region (1.97) than the backward region (1.36).

On the average the total output per holding shows a positive association with the ascending class status up to the rich peasant category and then shows a decline for the landlord (Table 4). The output per operated area on the other hand also shows the positive trend but in lesser extent. It increases from Rs 23676 for the poor peasant, to Rs 27644 for small peasant, to 30510 for the middle peasant, and then shows stagnancy at 30324 for the rich peasant and finally an increase to Rs 36880 for the landlord. The output per acre sown shows a smaller positive variation with ascending class than does the output per acre operated, owing to higher cropping intensity on the labour hiring farm. However, the labour hiring classes show a marginal higher yield performance than the exploited and the self-employed classes. The farm size shows almost stagnant magnitude of the output per operated and sown area. 
Table 4: Economic Class wise and Acreage Group wise Cropping Intensity and Structure of Output

\begin{tabular}{|c|c|c|c|c|c|c|c|}
\hline Class/Group & $\begin{array}{c}\text { No of } \\
\text { Hhs }\end{array}$ & $\begin{array}{c}\text { Total Area } \\
\text { Oprtd(acre) }\end{array}$ & $\begin{array}{l}\text { Total Sown } \\
\text { Area (acre) }\end{array}$ & $\begin{array}{l}\text { Cropping } \\
\text { Intensity }\end{array}$ & $\begin{array}{l}\text { Output (Rs) } \\
\text { Per Holding }\end{array}$ & $\begin{array}{c}\text { Output(Rs) per } \\
\text { area oprtd. }\end{array}$ & $\begin{array}{c}\text { Output(Rs) per } \\
\text { area Sown }\end{array}$ \\
\hline \multicolumn{8}{|l|}{ All Region } \\
\hline Landless & 70 & 0 & 0.00 & 0.00 & 0 & 0 & 0 \\
\hline Poor Peasant & 28 & 10.64 & 14.74 & 1.39 & 8995 & 23676 & 17087 \\
\hline Small Peasant & 23 & 17.14 & 25.73 & 1.50 & 20600 & 27644 & 18415 \\
\hline Middle Peasant & 28 & 35.99 & 58.62 & 1.63 & 39217 & 30510 & 18731 \\
\hline Rich Peasant & 39 & 70.00 & 106.79 & 1.53 & 54424 & 30324 & 19876 \\
\hline Landlord & 18 & 25.74 & 49.69 & 1.93 & 52728 & 36880 & 19100 \\
\hline Total & 206 & 159.49 & 255.58 & 1.60 & 23764 & 30694 & 19154 \\
\hline \multicolumn{8}{|l|}{ Advanced Region } \\
\hline Landless & 39 & 0.00 & 0.00 & 0.00 & 0 & 0 & 0 \\
\hline Poor Peasant & 13 & 5.01 & 6.14 & 1.23 & 10122 & 26292 & 21418 \\
\hline Small Peasant & 8 & 5.94 & 12.05 & 2.03 & 30243 & 40765 & 20086 \\
\hline Middle Peasant & 20 & 23.26 & 45.23 & 1.95 & 45544 & 39169 & 20137 \\
\hline Rich Peasant & 10 & 14.80 & 28.42 & 1.92 & 72621 & 49078 & 25552 \\
\hline Landlord & 11 & 13.96 & 32.46 & 2.32 & 60213 & 47430 & 20404 \\
\hline Total & 101 & 62.96 & 124.31 & 1.97 & 26465 & 42457 & 21502 \\
\hline \multicolumn{8}{|c|}{ Backward Region } \\
\hline Landless & 31 & 0.00 & 0.00 & 0.00 & 0 & 0 & 0 \\
\hline Poor Peasant & 15 & 5.63 & 8.60 & 1.53 & 8018 & 21370 & 13991 \\
\hline Small Peasant & 15 & 11.20 & 13.69 & 1.22 & 15458 & 20703 & 16943 \\
\hline Middle Peasant & 8 & 12.73 & 13.39 & 1.05 & 23400 & 14705 & 13981 \\
\hline Rich Peasant & 29 & 55.20 & 78.37 & 1.42 & 48150 & 25298 & 17818 \\
\hline Landlord & 7 & 11.78 & 17.23 & 1.46 & 40965 & 24353 & 16643 \\
\hline Total & 105 & 96.53 & 131.27 & 1.36 & 21166 & 23024 & 16930 \\
\hline \multicolumn{8}{|l|}{ All Region } \\
\hline 0.00 & 70.00 & 0.00 & 0.00 & 0.00 & 0 & 0 & 0 \\
\hline 0.01 to 1.25 & 91.00 & 50.08 & 83.62 & 1.67 & 18147 & 32972 & 19748 \\
\hline 1.25to 2.5 & 31.00 & 52.95 & 85.32 & 1.61 & 52594 & 30794 & 19109 \\
\hline 2.5 to 5 & 13.00 & 49.86 & 80.04 & 1.61 & 117664 & 30679 & 19111 \\
\hline $5 \&$ abv & 1.00 & 6.60 & 6.60 & 1.00 & 84000 & 12727 & 12727 \\
\hline Total & 206.00 & 159.49 & 255.58 & 1.60 & 23764 & 30694 & 19154 \\
\hline \multicolumn{8}{|c|}{ Advanced Region } \\
\hline 0.00 & 39.00 & 0.00 & 0.00 & 0.00 & 0 & 0 & 0 \\
\hline 0.01to 1.25 & 45.00 & 26.33 & 47.95 & 1.82 & 23432 & 40044 & 21990 \\
\hline 1.25to 2.5 & 13.00 & 22.93 & 47.58 & 2.08 & 75905 & 43034 & 20739 \\
\hline 2.5 to 5 & 4.00 & 13.70 & 28.78 & 2.10 & 157940 & 46131 & 21951 \\
\hline $5 \&$ abv & 0.00 & 0.00 & 0.00 & 0.00 & 0 & 0 & 0 \\
\hline Total & 101.00 & 62.96 & 124.31 & 1.97 & 26465 & 42457 & 21502 \\
\hline \multicolumn{8}{|c|}{ Backward Region } \\
\hline 0.00 & 31 & 0.00 & 0.00 & 0.00 & 0 & 0 & 0 \\
\hline 0.01 to 1.25 & 46 & 23.75 & 35.67 & 1.50 & 12976 & 25130 & 16734 \\
\hline 1.25 to 2.5 & 18 & 30.02 & 37.74 & 1.26 & 35759 & 21444 & 17055 \\
\hline 2.5 to 5 & 9 & 36.16 & 51.26 & 1.42 & 99764 & 24831 & 17516 \\
\hline $5 \&$ abv & 1 & 6.60 & 6.60 & 1.00 & 84000 & 12727 & 12727 \\
\hline Total & 105 & 96.53 & 131.27 & 1.36 & 21166 & 23024 & 16930 \\
\hline
\end{tabular}

To sum up, compared to all classes of exploited and self-employed, the labour hiring classes registers higher yield level. Thus our data decisively refute the populist view that family labour based farms are more 'efficient' in the sense of registering higher yields compared to hired labour based farms representing the capitalistic tendency, as had been argued by Chayanov (1966) and A. K. Sen (1966). This finding is particularly significant in the context of the rule of the Left Front and substantial tenancy reform through Operation Barga in West Bengal as well as the provision of credit to the 
disadvantaged. All this has provided a much more conducive climate for the small peasants and middle peasants to invest more in land than is the case in other states.

\section{CONCLUSION:}

We have seen that despite a strong pro poor state intervention in the state, the differentiation of the peasantry is still going on based on the higher command of resources by the labour hiring classes. This has been reflected in positive association between ascending classes / acreage groups and per acre and per holding productivity. Indeed the inequality prevails in the credit market is lesser than that of the other markets. But at the same time the credit market cannot cope with the growing demand for production loans particularly from the advanced region. Its inadequacy keeps the system of private money lending alive. In spite of the fact that the pre-capitalist institutions like market interlinkage has almost been disappeared, as we will see in the next chapter, noninstitutional credit remains the major source of borrowing for the rural poor.

\section{BIBLIOGRAPHY}

Azzi, C. F. and Cox, J.C. (1976), "A Theory and Test of credit Rationing : Comment", American Economic Review, December.

Bandyopadhyay, Abhijit Vinayak and Ghatak Maitresh (2000), (in Bengali) 'Pashchimbanger Krishi o Bamfronter Krishi Niti' Calcutta, Anandabazar Patrika, April 20.

Bardhan, P. (1970), "The Green Revolution and Agricultural Labourers", Economic and Political Weekly, Special Number, July.

Basu, K. (1983), "The Emergence of Isolation and Interlinkage in Rural Markets", Oxford Economic Papers, Vol.8, No.2.

Basu, K. (1984), "Implicit Interest Rates, Usury and Isolation in Backward Agriculture", Cambridge Journal of Economics, Vol.8, No.2.

Bell, C. (1990), "Interactions between Institutional and Informal Credit Agencies in Rural India", The World Bank Economic Review, September, Vol.4, No.3.

Bhaduri, A. (1973), "A study in Agricultural Backwardness under Semi-feudalism", Economic Journal, March

Bhaduri, A. (1984), The Economic Structure of Backward Agriculture, London, Academic press.

Bhaduri, A. (1993a), "On The Formation of Usurious Interest Rates in Backward Agriculture", in A. Bhaduri (ed.) Unconventional Economic Essays, Delhi, Oxford University Press.

Bhaduri, A. (1993b), "Class Relations and Patterns of Accumulation in an Agrarian Economy", in A. Bhaduri (ed.) Unconventional Economic Essays, Delhi, Oxford University Press. 
Bhaduri, A. (1993c), "The Evolution of Land Relations in Eastern India Under British Rule", in A. Bhaduri (ed.) Unconventional Economic Essays, Delhi, Oxford University Press.

Bhaduri, A. (1993d), "Mathematical Appendix: A Model of Differentiation among Initially Indebted Peasants", in A. Bhaduri (ed.) Unconventional Economic Essays, Delhi, Oxford University Press.

Bhattacharyya, Sudipta (2001), 'Capitalist Development, Peasant Differentiation and the State: Survey Findings from West Bengal', Journal of Personal Studies, Vol.28, No.4.

Bhaumik, Sankar Kumar (1993), Tenancy Relations and Agrarian Development, A Study of West Bengal, New Delhi. Sage.

Blinder, A.S. (1987), "Credit Rationing and Effective Supply Failures", Economic Journal, June.

Bottomley, Anthony (1964), "The determination of Pure Rates of Interest in Underdeveloped Rural Areas", Review of Economics and Statistics, Vol.46.

Byres, T. J. (1996), 'Introduction: Development Planning and the Interventionist State Versus Liberalisation and the Neo-liberal State: India, 1989-96', in State, Development Planning and Liberalisation in India, Delhi: Oxford University Press.

Centre for Monitoring the Indian Economy - CMIE (1993), Performance of Agriculture in Major States (1967-68 to 1991-92), July 1993.

Chayanov, A. V. (1966), Theory of Peasant Economy, Ed. by D. Thorner, R. E. F. Smith and B. Karblay, Homewood, Illinois, Irwin.

Chavan, Pallavi (2005) 'Banking Sector Liberalisation and the Growth and Regional Distribution of Rural Banking', Economic and Political Weekly, Special Issue on Microfinanace, Economic and Political Weekly, Vol. 40, No. 43 (Oct. 23-28), pp. 4647-4649.

Dasgupta, Biplab (1995), 'Institutional Reform and Poverty Alleviation in West Bengal' Economic and Political Weekly, October 14-21.

Datta Ray, S. (1994a), 'Agricultural Growth in West Bengal', Economic and Political Weekly, July16.

Datta Ray, S. , (1994b), 'Growth of Agriculture in West Bengal', Economic and Political Weekly, November 19. 
Eswaran M. and A. Kotwal (1989), "Credit and Agrarian Class Structure", in P. Bardhan, ed., The Economic Theory of Agrarian Institutions , Clarendon Press, Oxford.

Frank. S ; The Micro Finance Development and Regulation Bill, Regulation or Strangulation, Peoples Democracy, March 11, 2007, P-7.

Gothaskar, S.P. (1988), "On some Estimates of Rural Indebtedness", Reserve Bank of India Occassional Papers, Vol.1, No.4, December 1998.

Jaffee, D.M. and Russell, T. (1976), "Imperfect Information, Uncertainty, and Credit Rationing", Quarterly Journal of Economics.

Kalecki, Michal (1970), "Problems of Financing Economic Development in a Mixed Economy" in Michal Kalecki (1972) Selected Essays on the Economic Growth of the Socialist and the Mixed Economy, Cambridge, Cambridge University Press.

Kautsky, Karl (1988), The Agrarian Question, Vol.1, London, Zwan.

Lenin, V. I. (1970), Two Tactics of Social Democracy in the Russian Revolution, Selected Works, Vol. 1, Moscow, Progress Publishers.

Mukherjee, Badal and Mukhopadhyay, Swapna (1995), "Impact of Institutional Change on Productivity in a Small-Farm Economy: Case of Rural West Bengal", Economy and Political Weekly, August 26.

Nair, Tara. S. (2005) 'The Transforming World of Indian Microfinance', Economic and Political Weekly, Vol. 40, No. 17 (Apr. 23-29, 2005), pp. 1695-1698.

Patnaik Utsa (1987), Peasant Class Differentiation, A Study in Method with Reference to Haryana, Delhi, Oxford University Press.

Patnaik, Utsa (1988), "Ascertaining the Economic Characteristics of Peasant Classes-inThemselves in Rural India" Journal of Peasant Studies, Vol. 15, No.3, April.

Prabhu, K. Seeta, Nadkarni, Avadhoot and Achuthan, C. V. (1988), 'Rural Credit: Mystery of the Missing Households', Economic and Political Weekly, December 10 .

Reserve Bank of India (1974), Report of the Study Team on Overdues of Co-operative Credit Institutions, Bombay, Agricultural Credit Department.

Reserve Bank of India (1989), A Review of the Agricultural Credit System in India: Report of the Agricultural Credit Review Committee (Chairman: A.M.Khusro), Bombay.

Reserve Bank of India (1991), Report of the Committee on the Financial system (Chairman: M Narasimhan), Bombay.

Saha, Anamitra and Swaminathan, Madhura (1994a), "Agricultural Growth in West Bengal in the 1980s: A Disaggregation by Districts and Groups", Economic and Political Weekly, March 26. 
Sen, Abhijit and Sengupta, Ranja (1995), "The Recent Growth in Agricultural Output in Eastern India, with Special Reference to the Case of West Bengal", Paper Presented at a Workshop on 'Agricultural Growth and Agrarian Structure in Contemporary West Bengal and Bangladesh', Calcutta, January 1995.

Sen, Amartya and Sengupta, Sunil (1983), "Malnutrition of Rural Indian Children and Sex Bias", Economic and Political Weekly, Review of Agriculture, 16, (25-6).

Sen, A. K. (1996), "Peasant and Dualism With or Without Surplus Labour", Journal of Political Economy, 74.

Sengupta, Sunil and Gazdar, Haris (1998), "Agrarian Politics and Rural Development in West Bengal", in Jean Dreze and Amartya Sen (1997) edited Indian Development:

Selected Regional Perspectives, Clarendon Press, Oxford.

Stiglitz, J. E. and Weiss, A. (1981), "Credit Rationing in Markets with Imperfect Information", American Economic Review, June.

Swaminathan, Madhura (1991), 'Segmentation, Collateral Undervaluation, and the Rate of Interest in Agrarian Credit Markets: Some Evidence from Two Villages in South India', Cambridge Journal of Economics, 15, 161-178.

Swaminathan, Madhura and Ramchandran, V. K. (1999), 'New Data on Calorie Intakes', Frontline, March 12.

Ramchandran And Swaminathan (2002), Rural Banking And Landless Labour Households: Institutional Reform And Rural Credit Markets In India, Journal Of Agrarian Change, Vol. 2, No. 4, October, Pp.502-44. 


\section{APPENDIX - I \\ SELECTION OF THE SAMPLE BLOCKS:}

Two sample blocks have been selected on the basis of level of economic development. One block is Nalhati-II which seems to be the most advanced and most prosperous in the district. Other block is Illambazar which seems to be the most backward.

The selection of the sample block is preceded by the selection of sample thanas, since the 'District Census Handbook' presents data for various developmental indicators only on the basis of thanas. The following developmental variables have been chosen to identify the blocks with high and low level of development:

1. Percentage of literacy (X1).

2. Percentage of school and college per square kilometre (X2).

3. Average students per institution (X3).

4. Average teachers per institution (X4).

5. Percentage of medical institution and welfare centre per square $\mathrm{km}(\mathrm{X} 5)$.

6. Average number of beds per medical institution (X6).

7. Average number of doctors per medical institution (X7).

8. Average number of immunization programme per medical institution (X8).

9. Population served per commercial and grameen bank office in ' 000 (X9).

On the basis of the above indicators the advanced and the backward thanas have been identified in Table A-I. For every indicator in each thana the value is compared to the district average. If it is above the average, it is noted down as A (for advanced) and B (for backward) when the same is below the average. In this way if a particular thana has above average performance for all the seven variables, it is given a grade of A+. Similarly if a thana has lower than the district average figure for all the variables it is given a grade of C-. There are several intermediary grades (as shown and explained in the Table A-I) depending upon the relative performance of the different indicators. It is evident from the Table A-I that Nalhati - II comes out as the most developed thana with A grade and Illambazar comes out as the most backward thana with the grade of $\mathrm{C}$. 
Table A-I: Selection of Blocks

\begin{tabular}{|c|c|c|c|c|c|c|c|c|c|c|c|c|c|c|}
\hline Sub-div & Blocks & $\mathbf{X 1}$ & $\mathbf{X 2}$ & $\mathbf{X 3}$ & $\mathrm{X} 4$ & X5 & X6 & $\mathbf{X} 7$ & X8 & X9 & Total A & Total B & Grades & Remarks \\
\hline \multirow[t]{8}{*}{ Rampurhat } & Nalhati 1 & 63.70 & 60.87 & 221.65 & 4.95 & 15.62 & 13.00 & 1.20 & 856.23 & 23.18 & 6 & 3 & A- & Advanced Marginally \\
\hline & Nalhati 2 & 61.60 & 75.13 & 236.22 & 5.61 & 18.32 & 10.33 & 0.67 & 987.45 & 17.94 & 7 & 2 & A & Advanced More or Less \\
\hline & Murarai 1 & 46.60 & 66.09 & 330.50 & 3.80 & 16.52 & 25.33 & 2.67 & 894.21 & 19.29 & 7 & 2 & $\mathbf{A}$ & Advanced More or Less \\
\hline & Murarai 2 & 46.20 & 55.58 & 322.76 & 5.35 & 17.81 & 8.60 & 1.20 & 879.33 & 29.62 & 5 & 4 & $\mathbf{B}+$ & Moderately Devloped \\
\hline & Mayureswar 1 & 65.40 & 60.49 & 247.98 & 4.68 & 11.12 & 10.33 & 1.33 & 784.80 & 12.70 & 3 & 6 & $\mathrm{C}+$ & Backward Marginally \\
\hline & Mayureswar 2 & 62.80 & 65.15 & 206.70 & 4.76 & 14.69 & 13.00 & 0.75 & 627.87 & 22.61 & 4 & 5 & B- & Moderately Underdevloped \\
\hline & Rampurhat1 & 61.90 & 57.71 & 201.52 & 3.75 & 11.47 & 49.86 & 5.57 & 573.88 & 9.36 & 3 & 6 & $\mathrm{C}+$ & Backward Marginally \\
\hline & Rampurhat2 & 63.50 & 74.91 & 235.71 & 4.94 & 17.08 & 13.00 & 1.75 & 708.77 & 19.84 & 5 & 4 & B+ & Moderately Devloped \\
\hline \multirow[t]{7}{*}{ Sadar } & Md.Bazar & 55.10 & 44.99 & 227.29 & 4.95 & 9.50 & 10.67 & 1.17 & 700.37 & 12.68 & 2 & 7 & $\mathbf{C}$ & Backward More or Less \\
\hline & Sainthia & 64.40 & 65.71 & 159.20 & 4.34 & 12.48 & 7.83 & 0.83 & 664.82 & 12.55 & 2 & 7 & $\mathbf{C}$ & Backward More or Less \\
\hline & Dubrajpur & 56.70 & 49.87 & 163.38 & 3.91 & 10.15 & 59.67 & 1.50 & 687.06 & 13.25 & 1 & 8 & $\mathbf{C}$ & Backward More or Less \\
\hline & Rajnagar & 58.30 & 45.60 & 126.49 & 3.35 & 8.13 & 10.33 & 1.00 & 645.56 & 11.62 & 0 & 9 & C- & Backward Very High \\
\hline & Suri 1 & 62.50 & 63.37 & 216.00 & 4.86 & 12.93 & 14.40 & 0.80 & 742.20 & 6.03 & 2 & 7 & C & Backward More or Less \\
\hline & Suri 2 & 63.80 & 64.80 & 207.51 & 4.75 & 11.78 & 10.33 & 1.00 & 788.50 & 8.56 & 2 & 7 & $\mathbf{C}$ & Backward More or Less \\
\hline & Khoyrasole & 60.50 & 51.80 & 194.55 & 4.17 & 9.92 & 9.25 & 1.50 & 660.26 & 22.52 & 2 & 7 & $\mathbf{C}$ & Backward More or Less \\
\hline \multirow[t]{4}{*}{ Bolpur } & Bolpur-Sriniketan & 60.00 & 51.71 & 194.18 & 5.32 & 11.66 & 27.10 & 3.10 & 648.05 & 9.90 & 4 & 5 & B- & Moderately Underdevloped \\
\hline & Labhpur & 62.10 & 69.41 & 183.31 & 4.84 & 13.43 & 10.67 & 1.83 & 740.17 & 19.65 & 4 & 5 & B- & Moderately Underdevloped \\
\hline & Nanoor & 61.20 & 59.97 & 206.11 & 4.98 & 12.19 & 8.40 & 1.40 & 800.74 & 13.84 & 2 & 7 & $\mathbf{C}$ & Backward More or Less \\
\hline & Illambazar & 63.00 & 58.88 & 170.62 & 4.27 & 10.32 & 12.75 & 1.50 & 689.96 & 16.13 & 2 & 7 & C & Backward More or Less \\
\hline \multicolumn{2}{|c|}{ Birbhum District } & 59.90 & 61.58 & 219.15 & 4.95 & 12.96 & 22.12 & 2.00 & 754.91 & 15.54 & & & & \\
\hline
\end{tabular}




\section{APPENDIX - II \\ PATNAIK'S LABOUR EXPLOITATION CRITERION}

The Marxist concept of the process of class differentiation is that, under a regime of commodity production, the rich peasant class increasingly employs the labour of others and thereby appropriates surplus. A poor peasant on the other hand is increasingly obliged to work for others and is thereby increasingly subjected to exploitation. The self-employed are in a vulnerable position. While a few of them might be able to transform themselves into rich peasant, the majority of them are always under the constant threat of being pushed down into the ranks of the semi-proletariat. At one of the two poles of the rural class structure, and more or less distinct from the peasantry, stands the landlord, defined by 'possession of substantial means of production and non-involvement in any manual labour, living entirely by appropriating surplus labour of others'. The landless labourer has no self-employment, for he posses no means of production at all and is obliged to live entirely by selling his labour.

The labour-exploitation index seeks to give an empirical approximation to the analytical concept of the class status of the household. The class-status is essentially determined by the extent of the use of outside labour or to the extent the family works for others, relative to the extent of self-employment. It is identical, under certain simplifying assumptions with the surplus labour appropriated or parted with, relative to surplus labour with self-employment.

$$
\mathbf{E}=\mathbf{X} / \mathbf{Y}=\{(\text { Hi-Ho })+(\text { Lo-Li) }\} / \mathbf{F}
$$

Where, $\quad \mathrm{Hi}=$ Labour-days hired on the operational holding of the household

Ho $=$ Family labour days hired out to others

$\mathrm{Li}=$ Labour days worked on leased in land (whether by family or hired labour)

Lo $=$ Labour days similarly worked on land leased out by the household

$\mathrm{F}=$ Labour days worked by household workers on the operational holding.

The index is a ratio, or a pure number, which can have positive or negative values depending on whether the household is a net employer of outside labour or is itself on balance working for others (as labourer or tenant). The range of values of $\mathrm{E}$ is from plus infinity to minus infinity, for at the two poles of the rural class structure, there will be diametrically opposite types of households for whom $\mathrm{F}$ will be zero or near zero: first, the big landlords have such a large resource endowment that they perform no manual labour themselves, but rely entirely on employing others' labour; and the landless labourers, with zero resource endowment, hence zero self-employment, who are entirely dependent on working for others'. (Patnaik, 1988; p.305)

Classes within the cultivating peasantry are identified by looking at the degree of working for others or of employing others' labour, relative to self employment. For this purpose certain limits are set upon the values of the E-ratio which are given in the following Table. All subsequent use of class categories in this book refers to the definitions given in the Table-A.II which is taken from Patnaik $(1976,1987)$. 


\section{TABLE - A.1I: Patnaik's E-Criteria}

The following limits are specified to the value of $\mathrm{E}$ in order to classify households into a set of mutually exclusive and all-exhaustive categories (sub-categories not specified here are not ruled out)

\begin{tabular}{|c|c|c|c|}
\hline Class & Defining Characteristic & $\begin{array}{l}\text { Value of } \\
E=X / F\end{array}$ & Reason \\
\hline $\begin{array}{l}\text { 1. Landless } \\
\text { labourers }\end{array}$ & $\begin{array}{l}\text { No self-employment; working } \\
\text { entirely for others }\end{array}$ & $(\mathrm{E} \rightarrow-\infty)$ & $\begin{array}{l}\mathrm{F}=0 \\
\mathrm{X}<0 \\
\text { and large }\end{array}$ \\
\hline $\begin{array}{l}\text { 2. Poor peasant } \\
\text { (Poor tenant and } \\
\text { labourer with land) }\end{array}$ & $\begin{array}{l}\text { Working for others to a } \\
\text { greater extent than self- } \\
\text { employment }\end{array}$ & $(\mathrm{E} \leq-1)$ & $\begin{array}{l}F>0 \\
X<0 \\
|X| \geq F\end{array}$ \\
\hline 3. Small peasant & $\begin{array}{l}\text { Zero employment of others or } \\
\text { working for others ; and } \\
\text { working for others to smaller } \\
\text { extent than self-employment }\end{array}$ & $(0 \geq E>-1)$ & $\begin{array}{l}F>0 \\
X \leq 0 \\
|X|<F\end{array}$ \\
\hline 4. Middle peasant & $\begin{array}{l}\text { Smaller employment of } \\
\text { others' labour than self- } \\
\text { employment }\end{array}$ & $(1>\mathrm{E}>0)$ & $\begin{array}{l}F>0 \\
X>0 \\
X<F\end{array}$ \\
\hline 5. Rich peasant & $\begin{array}{l}\text { At least as large an } \\
\text { employment of others' labour } \\
\text { as self-employment }\end{array}$ & $(E \geq 1)$ & $\begin{array}{l}F>0 \\
X>0 \\
X \geq F\end{array}$ \\
\hline 6. Landlord & $\begin{array}{l}\text { No manual labour in self- } \\
\text { employment, large } \\
\text { employment of others' labour }\end{array}$ & $(E \rightarrow \infty)$ & $\begin{array}{l}\mathrm{F}=0 \\
\mathrm{X}>0 \\
\text { and large }\end{array}$ \\
\hline
\end{tabular}

Source: Utsa Patnaik (1987), Peasant Class Differentiation: A Study in Method with Reference to Haryana, Delhi, Oxford University Press. 